\title{
7000系高力アルミニウム合金の過時効処理における 分散相上の不均一析出*
}

\author{
荒木一郎**。菅野 幹宏*** ·崔祺**** \\ Heterogeneous precipitation on dispersoids in 7000 high strength \\ aluminum alloys during overaged temper*
}

Ichiro ARAKI**, Motohiro KANNO*** and Qi CUI****

\begin{abstract}
Preferred precipitation of the $\eta$ phase on dispersoids was examined in the 7075, 7050 alloys and 7075 ( $\mathrm{Zr}$ ) alloy containing $\mathrm{Zr}$ instead of $\mathrm{Cr}$ under the conventional overaged temper. Specimens were solution treated at $470^{\circ} \mathrm{C}$, preaged at $120^{\circ} \mathrm{C}$ for $86.4 \mathrm{ks}$ and finally aged at $(163-170)^{\circ} \mathrm{C}$. The $\eta$ precipitates nucleate on incoherent dispersoid of the $\mathrm{E}\left(\mathrm{Al}_{18}\right.$ $\left.\mathrm{Cr}_{2} \mathrm{Mg}_{3}\right)$ phase inside the grain of the 7075 alloy. This causes serious loss of strength during overaging. Coherent dispersoids of the $\mathrm{Al}_{3} \mathrm{Zr}$ phase do not act as the nucleation site for $\boldsymbol{\eta}$ precipitates in the 7050 . Therefore, $\boldsymbol{\eta}$ precipitates appeare only on grain boundaries in the 7050 alloy. The substitution of $\mathrm{Cr}$ by $\mathrm{Zr}$ in 7075 alloy is found to improve the strength after the conventional overaged temper.
\end{abstract}

Keywords: $\mathrm{Al}_{3} \mathrm{Zr}$ dispersoid, recrystallization, heterogeneous nucleation, coherency, overaging

(Received March 29, 1993)

\section{1. 緒言}

実用高力アルミニウム合金には再結晶抑制の目的で, $\mathrm{Cr}, \mathrm{Zr}, \mathrm{Mn}$ などが添加されてきている。これらの遷移 元素は固相のアルミニウムに対する固溶度がきわめて小 さいため, 鋳塊の均質化処理の際に析出し, いわゆる Dispersoid（分散相）を形成する。この分散相はその後 の溶体化処理時に打汀る再結晶を抑制 ${ }^{1)}$ し, 延性, 勒 性，耐 SCG 性を向上させるとされる。

実用合金の5ち最も高力となる7000系合金では，T6 処理状態での耐 SCC 性がきわめて悪いので，いわゆる 過時効処理として知られる T73調質およびT76調質が開 発されている2 〜4)。これらはいずれも高温での二段時効 処理を含んでおり，その結果粒界上析出物が粗大化する ため, 耐 SCC 性や耐剝離性が向上するが5), 強度は T6 に比べてかなり低下する（T73で約10〜15\%，T76で約 $10 \%)^{2), 3)}$ 。この過時効処理による強度低下については
粒内析出相の粗大化 ${ }^{6)}$ あるいは準安定相の安定相への変 態)などが原因と考えられている。しかし，焼入れ感受 性に関連する諸結果 ${ }^{7) ~ 9) ~}$ を参照すると, 分散相の界面が 安定相の不均一析出サイトとなる可能性があり，このこ とも過時効処理での強度低下と関連があるものと思われ る。しかし，これまでそのような観点からの検討はほと んぞなされていない。そこで，本研究ではこれら過時効 処理における不均一析出と分散相との関係を調べること にした。

\section{2. 試料および実験方法}

試料としては，市販の7075合金および7050合金（いず れも熱間圧延板，板厚 $7 \mathrm{~mm}$ ）を用いた。また参考のた めに7075合金相当の溶製材7075 (Cr)，および7075合金 の Crを Zr で置換した溶製材7075（Zr）をそれぞれ熱間 圧延した状態で使用した。各合金の分析値を Table 1 に示す。これらの板の一部を冷間圧延（加工度 $80 \%$ ）し

\footnotetext{
* 軽金属学会第80回春期大会（平成 3 年 5 月）で一部発表。

** 新潟大学教育学部 (新潟市)。Faculty of Education, Niigata University (Niigata-shi, Niigata).

*** 東京大学工学部 (東京都)。Faculty of Engineering, The University of Tokyo (Bunkyo-ku, Tokyo).

**** 東京大学大学院 (東京都)。Graduate School, The University of Tokyo (Bunkyo-ku, Tokyo).
} 
Table 1 Chemical compositions of specimens (mass\%)

\begin{tabular}{l|ccccc}
\hline \hline Specimens & $\mathrm{Zn}$ & $\mathrm{Mg}$ & $\mathrm{Cu}$ & $\mathrm{Cr}$ & $\mathrm{Zr}$ \\
\hline 7075 alloy & 5.6 & 2.5 & 1.5 & 0.2 & - \\
7050 alloy & 6.0 & 2.2 & 2.0 & - & 0.12 \\
$7075(\mathrm{Zr})$ & 5.5 & 2.3 & 1.5 & - & 0.12 \\
$7075(\mathrm{Cr})$ & 5.6 & 2.4 & 1.5 & 0.21 & - \\
\hline
\end{tabular}

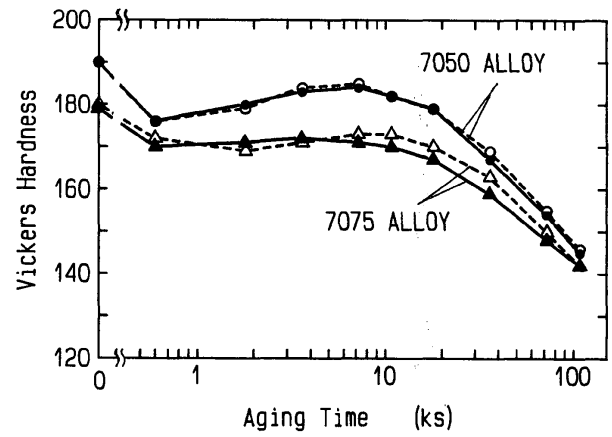

Fig. 1 Vickers hardness of 7075 and 7050 alloy, preaged at $120^{\circ} \mathrm{C}$ for $86.4 \mathrm{ks}$ (solid line) or $173 \mathrm{ks}$ (broken line), and subsequently aged at $170^{\circ} \mathrm{C}$ for various times.

た試料も用いた。

溶体化処理は $470^{\circ} \mathrm{C} て ゙ 7.2 \mathrm{ks}$ とし, 水焼入れ後, はし めに $\mathrm{T} 6$ 時効処理 $\left(120^{\circ} \mathrm{C}\right.$ で $86.4 \mathrm{ks}, 173 \mathrm{ks}$ 長時間時効も 併用）を行い，続いて高温での時効（170 ${ }^{\circ} \mathrm{C}$ 時効）を行 って過時効化させた。な執熱延材，冷延材のいずれの場 合も溶体化，焼入れ時の試料の厚さは $1.5 \mathrm{~mm}$ となるよ らにあらかじめ研削調整した。

これらの熱処理を行った試料に対し，ビッカース硬さ 測定およびTEMによる内部組織の観察を行った。 TEM 用薄膜は機械研磨, 電解研磨によって作製し, $200 \mathrm{kV}$ の透過電子顕微鏡（H-700）を用いて観察した。

\section{3. 実験結果および考察}

まずはじめに二段時効の概要を見るために，7075合金 および7050合金について, $120^{\circ} \mathrm{C} て ゙ 86.4 \mathrm{ks}$ の $\mathrm{T} 6$ 時効後, $170^{\circ} \mathrm{C}$ で最終時効したときの硬さ変化を調べた。結果を Fig. 1 亿実線で示す。いずれも二段時効の初期には硬さ の低下すなわち復元現象が認められるが，その後やや硬 化して，3〜7 ks でピークに達し, その後軟化する。過 時効処理はいずれもこの軟化した部分 $(18 〜 36 \mathrm{ks})$ で 行われるので，T6よりる硬さがかなり低くなる。7050 合金は7075合金と比べて全体便さレベルが高かった が，これは前者の方が溶質元素量が多いためと思われ る。また両合金において過時効処理に上る強度の低下量 には大差がないよらに見える。

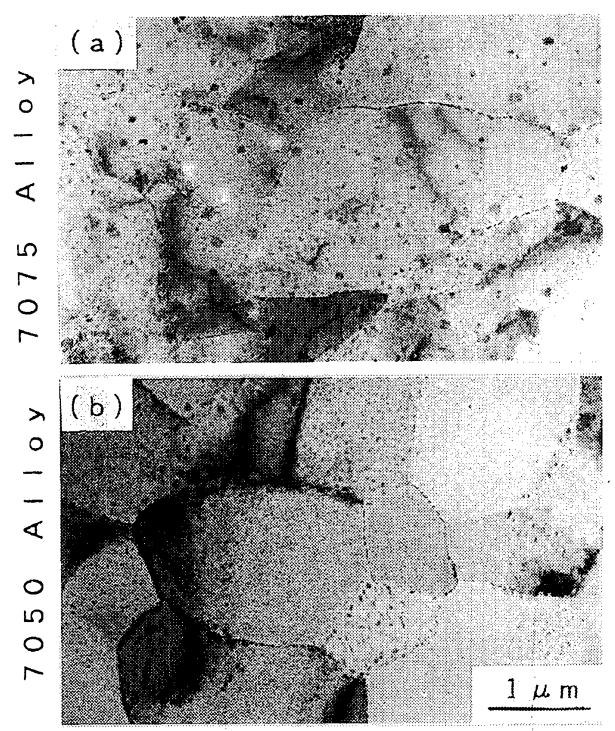

Fig. 2 Grain boundary precipitates of 7075 and 7050 alloy, preaged at $120^{\circ} \mathrm{C}$ for $86.4 \mathrm{ks}$ and aged at $170^{\circ} \mathrm{C}$ for $18 \mathrm{ks}$.

な初段時効時間を $173 \mathrm{ks}$ と長くしたときの硬さ变化 も調べ，図中に破線で併記した。これは初段時効時間を 長くすることによってマトリックス中の溶質量が低下 し, 最終時効での安定相の析出が遅くなるといら効果を ねらったものである。この場合いずれの合金も二段時効 初期の復元軟化にやや時間がかかるようであるが，過時 効軟化速度には初段時効時間の影響はほとんど見られな かった。

Fig. 2 には7075合金，7050合金のそれぞれについて， $120^{\circ} \mathrm{C}-86.4 \mathrm{ks}$ の初段時効後, $170^{\circ} \mathrm{C}$ で $18 \mathrm{ks}$ 時効したと きの TEM 組織を示した。これらの組織によれば，7075 合金，7050合金のいずれにおいても，未再結晶組織（亜 結晶粒径数 $\mu \mathrm{m})$ となって拉り，サブバウンダリー上に は安定相 $\eta$ の不均一析出が認められる。また7075合金 の場合，分散相として直径約0.1 0.2 $\mu \mathrm{m}$ の $\mathrm{E}$ 相 $\left(\mathrm{Al}_{18}\right.$ $\left.\mathrm{Cr}_{2} \mathrm{Mg}_{3}\right)^{10)}$ が数多く分布する(分布密度は約 $4 \times 10^{15} / \mathrm{m}^{3}$ )。

Fig. 3 は Fig. 2 と同一の試料についての高倍率の組 織を示す。いずれの合金においてもマトリックスに $\eta^{\prime}$ 相が高密度微細に析出している。さらに，7075合金で見 られる $\mathrm{E}$ 相はマトリックスに対して非整合な界面を持 ち，二段時効処理によって表面に安定相 $\eta$ の不均一析 出を生じている（a四に矢印で示す）。7050合金の場合 には，安定相の析出は粒界打よびサブバウンダリーにの み認められ，マトリックスに存在する直径約 $10 \mathrm{~nm}$ の微 細な $\mathrm{Al}_{3} \mathrm{Zr}$ 相（b 図矢印）への不均一析出は生じていな い。これら未再結晶組織内の $\mathrm{Al}_{3} \mathrm{Zr}$ 相は格子像によって も整合であることが確認されて扮り ${ }^{11)}$ ，b図に矢印で示 

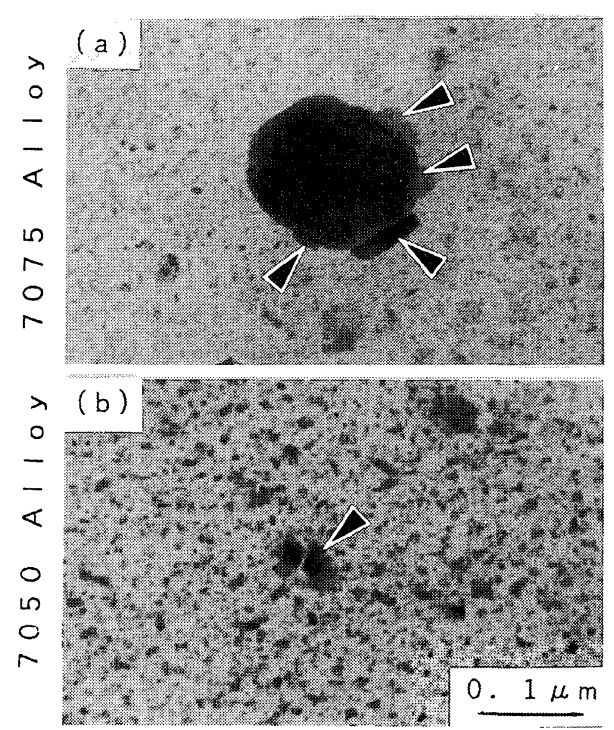

Fig. 3 TEM micrographs of 7075 and 7050 alloy corresponding to Fig. 2. Heterogeneous precipitation of $\eta$ on $\mathrm{E}$ phase is shown by the arrows in (a). Coherent $\mathrm{Al}_{3} \mathrm{Zr}$ phase (arrow in b) has no stable phase on its surface.

したように整合歪みが観察される。このような組織観察 から, $\mathrm{Zr}$ 添加合金で見られる $\mathrm{Al}_{3} \mathrm{Zr}$ 相は熱間加工材を 熱処理した場合には再結晶を生じないためマトリックス と整合であり，Cr含有合金で見られる $\mathrm{E}$ 相と異なっ て，安定相の析出サイトにはならない》。

このように見てくると，7050合金は7075合金と比べて 安定相の析出サイトがかなり少ないと考兄られる。る し, 過時効処理時の強度低下の一因が安定相の析出 (硬 化相の体積率減少）にもあるとするならば，7050合金は 安定相の析出サイトが少ない分だけ強度低下が抑えられ るはずである。しかし，7050合金と7075合金とでは既述 のよ5に溶質量が異なるので, 時効後の強度（硬さ）を 直接比較することができない。そこで，7075合金の Cr を $\mathrm{Zr}$ と置換した7075 (Zr) 合金と，7075合金に相当す る7075 (Cr) 合金の熱間圧延材を二段時効したときの硬 さ変化を調べた。結果を Fig. 4 に示す。この場合の熱 処理は7075合金の通常の T73処理にあわせて, 初段時効 は $107^{\circ} \mathrm{C} て ゙ 25.2 \mathrm{ks}$ 行い, 二段目は $163^{\circ} \mathrm{C} て ゙$ 時効した》。 T73に相当する長時間の時効（約 $108 \mathrm{ks}$ ）では, 予想ど おり $\mathrm{Zr}$ 含有合金の方が硬さの低下が少なく， Cr 含有合 金に比べて過時効処理後においても高い強度を保持する ことが実証された。

これらの合金の初段時効後の組織を Fig. 5 に, また その後 $163^{\circ} \mathrm{C} て ゙ 108 \mathrm{ks}$ 時効したときの過時効組織を Fig. 6 亿示す。初段時効組織では, Cr 含有合金は $\mathrm{E}$ 相が,

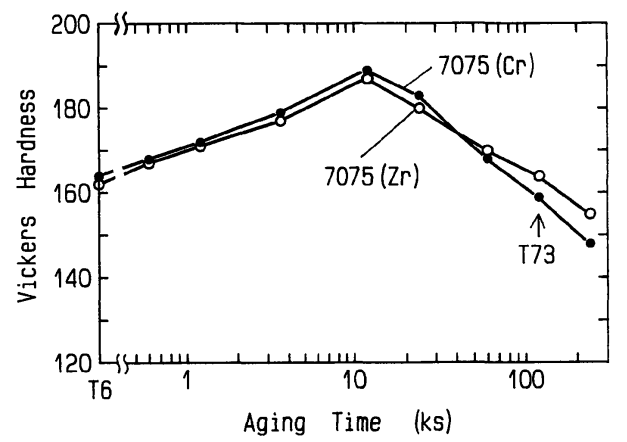

Fig. 4. Vickers hardness of $7075(\mathrm{Cr})$ and $7075(\mathrm{Zr})$ alloy, preaged at $107^{\circ} \mathrm{C}$ for $25.2 \mathrm{ks}$ and finally aged at $163^{\circ} \mathrm{C}$ for various times: $\mathrm{T} 73$ condition is also indicated.
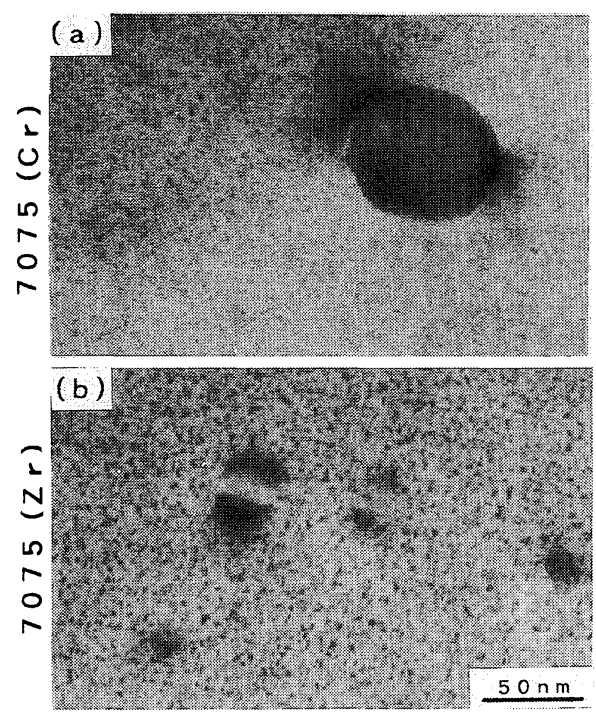

Fig. 5 TEM micrographs of $7075(\mathrm{Cr})$ and 7075

$(\mathrm{Zr})$ alloy preaged at $107^{\circ} \mathrm{C}$ for $25.2 \mathrm{ks}$.

また $\mathrm{Zr}$ 含有合金は整合な $\mathrm{Al}_{3} \mathrm{Zr}$ 相がいずれも微細な GP ゾーンや $\eta^{\prime}$ 相とともに認められる。過時効組織では マトリックス中の $\eta^{\prime}$ が粗大化するとともに, サブバウ ンダリ一上に安定相の析出が見られる。Cr 含有合金で は E 相上にも安定相が不均一析出する (Fig. 6-b 図矢 印)。これに対し $\mathrm{Zr}$ 含有合金ではサブバウンダリー上 に安定相が析出するのみで, マトリックスでは $\mathrm{Al}_{3} \mathrm{Zr}$ が 整合のため安定相の不均一析出が見られない。その結 果, 安定相の析出量は Cr 含有合金より少なくなる。こ のような時効組織は $\mathrm{Zr}$ 含有合金が過時効処理後におい ても比較的硬さが高いといら上記の結果（Fig. 4）をよ く説明している。

以上のよらに, 7000系合金の過時効処理においては, 安定相の析出に分散相の整合性が重要であることがわか 

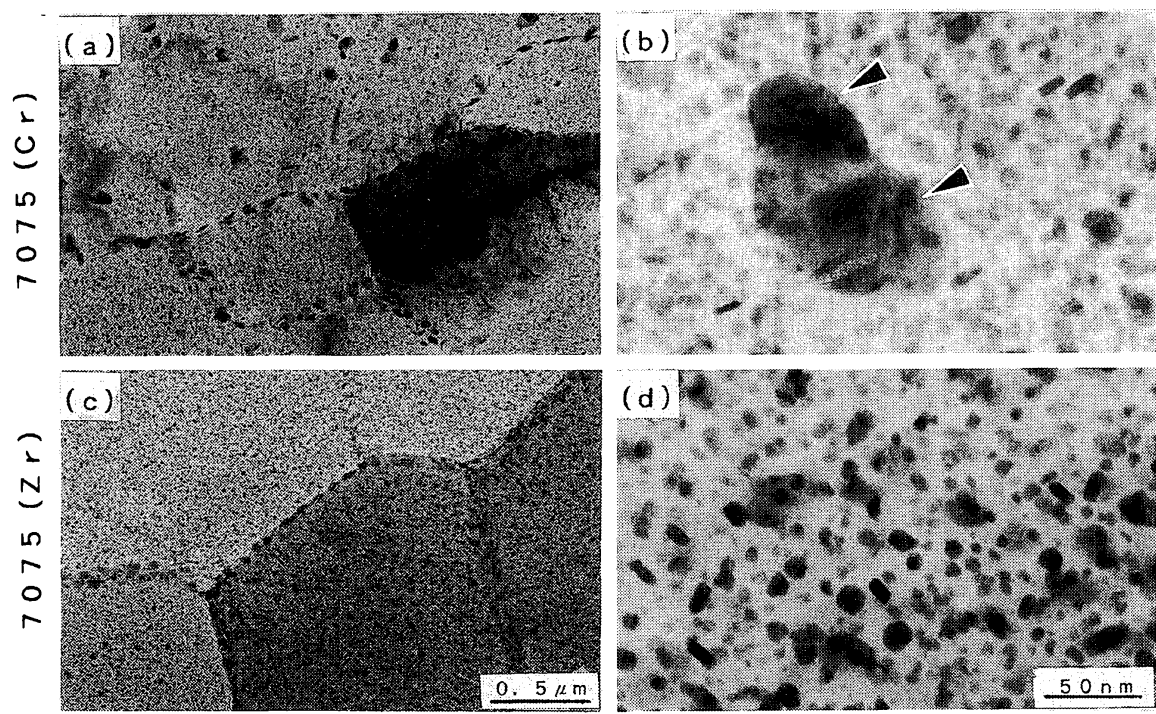

Fig. 6 TEM micrographs of $7075(\mathrm{Cr})$ and $7075(\mathrm{Zr})$ alloy after T73 treatment: preaged at $107^{\circ} \mathrm{C}$ for $25.2 \mathrm{ks}$ and aged at $163^{\circ} \mathrm{C}$ for $108 \mathrm{ks} . \eta$ phases (arrows in b) preferably formed on $\mathrm{E}$ phase.

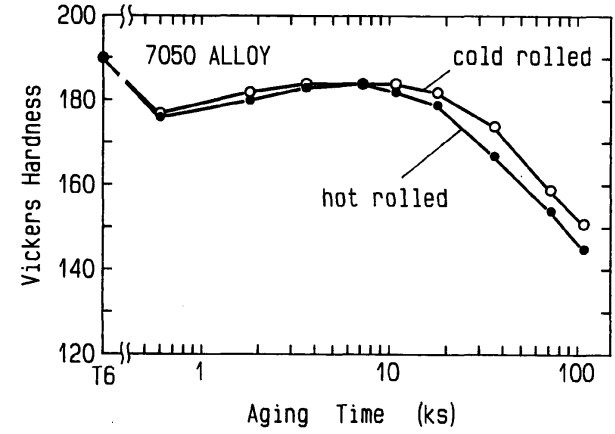

Fig. 7 Vickers hardness of 7050 alloy, preaged at $120^{\circ} \mathrm{C}$ for $86.4 \mathrm{ks}$ and aged at $170^{\circ} \mathrm{C}$ for various times: hot rolled specimen has higher softening rate during $170^{\circ} \mathrm{C}$ aging than cold rolled one.

った。ところで，焼入れ感受性に関する研究から7050合 金では冷間加工された場合，溶体化処理後の徐冷中に $350^{\circ} \mathrm{C}$ 付近で安定相が不均一析出しやすくなることがわ かっている7)。そこで過時効処理の場合にも冷間加工材 の方が不均一析出量が多くなるかどらかについて調べて みた。7050合金の熱延材，冷延材を $120^{\circ} \mathrm{C}-86.4 \mathrm{ks}$ の T6 時効後 $170^{\circ} \mathrm{C}$ で二段時効したときの硬さ測定の結果を Fig. 7 に示した。これによれば過時効処理後において, 冷延材の方が硬さレベルが高くなった。以下この理由に ついて検討する。

まず，熱延材，冷延材の両試料について，既報7) と同 様に $350^{\circ} \mathrm{C} て ゙ 30 \mathrm{~s}$ の焼入れ中断処理を行い，その後の時 効硬さ $\left(120^{\circ} \mathrm{C}-86.4 \mathrm{ks}\right)$ を調べた。その結果時効硬さは
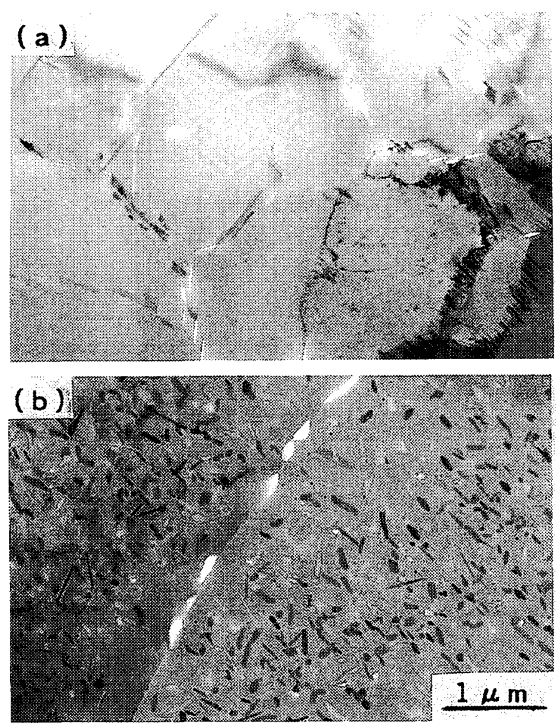

Fig. 8 TEM micrographs of 7050 alloy (a; hot-rolled, b; cold-rolled), quench-interrupted at $350^{\circ} \mathrm{C}$ for $30 \mathrm{~s}$ and aged at $120^{\circ} \mathrm{C}$ for $86.4 \mathrm{ks}$.

熱延材で $\mathrm{HV}=143$ ，冷延材で $\mathrm{HV}=119$ となり，本研究 で用いた7050合金の場合も冷延材の時効硬化能がきわめ て低くなることが確かめられた。これらに対応する時効 組織（Fig. 8) によれば熱延材（a図）はサブバゥンダ リ一上に安定相を生じるのみであるのに対し，冷延材 (b 図) では粒界上のみならず粒内の $\mathrm{Al}_{3} \mathrm{Zr}$ 相（非整合） 上へ析出した安定相が数多く認められる。これらの安定 相はいずれも焼入れ中断処理中に生じたものであるが， 


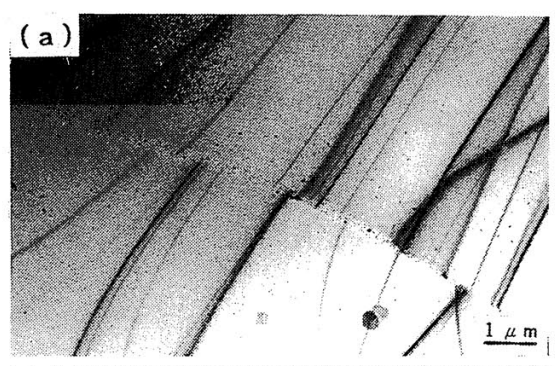

(b)

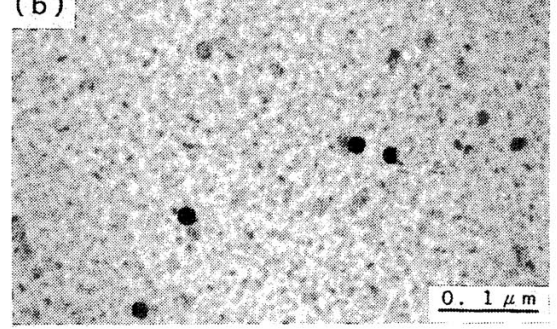

Fig. 9 TEM micrographs of 7050 alloy (cold rolled), preaged at $120^{\circ} \mathrm{C}$ for $86.4 \mathrm{ks}$ and aged at $170^{\circ} \mathrm{C}$ for $18 \mathrm{ks}$.

その全析出量は写真からも明らかなように冷延材の方が 多くなっており，時効硬化能が冷延材で低下した結果を よく説明している。

次に冷延材の焼入れ中断処理を行わなかったときの過 時効組織について検討した。Fig. 9 には7050合金の冷延 材について Fig. 2, Fig. 3 に対応する時効組織を示した。 低倍組織（a図）では再結晶組織となっていることがわ かり，粒界上析出も見られる。粒内の高倍組織（b 図） では高密度に $\eta^{\prime}$ 相が析出した組織となっているが，非 整合な $\mathrm{Al}_{3} \mathrm{Zr}$ 相も数多く見られ，それらに不均一析出し た安定相 $\eta$ がわずかに認められる。二段時効をさらに 長時間行った場合の組織 $\left(170^{\circ} \mathrm{C}-108 \mathrm{ks}\right)$ を Fig. 10 示したが，ここでは非整合な $\mathrm{Al}_{3} \mathrm{Zr}$ 相上に不均一析出し た $\eta$ 相の成長していることがわかる。このように7050 合金の冷延材を過時効処理した場合，非整合な $\mathrm{Al}_{3} \mathrm{Zr}$ 相 上へ $\boldsymbol{\eta}$ 相が不均一析出する現象は, 焼入れ中断処理 （Fig. 8）と共通する結果といえる。しかし，その不均 一析出量は焼入れ中断処理の場合と比べるとかなり少な い。これは焼入れ中断処理の場合の $350^{\circ} \mathrm{C}-30 \mathrm{~s}$ 保持中の 拡散が $170^{\circ} \mathrm{C}$ 時効中のそれより速かったことによろう。 熱延材と冷延材とを比較すると, 後者においてのみ安定 相の非整合 $\mathrm{Al}_{3} \mathrm{Zr}$ 相への不均一析出がみられるので，冷 延材の方が過時効軟化しにくいという結果（Fig. 7）は 今のところよくわからない。冷延材では粒界（亜粒界） 上への安定相の析出が熱延材より少ないので, 結果的に 安定相の析出総量が少なくなったとも考えられる。いず れにしても，勒性，耐 SCC 性を向上させるために一般

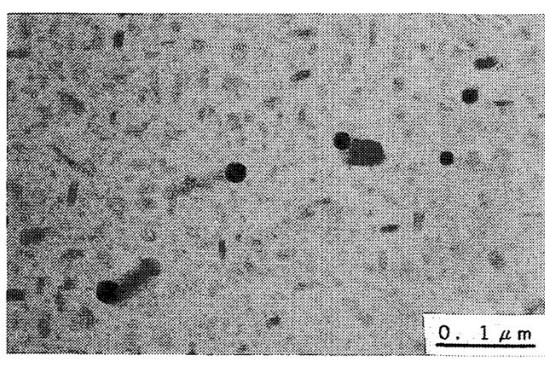

Fig. 10 Heterogeneous precipitation of $\eta$ at incoherent $\mathrm{Al}_{3} \mathrm{Zr}$ phases in 7050 alloy (cold rolled) after overaging: preaged at $120^{\circ} \mathrm{C}$ and aged at $170^{\circ} \mathrm{C}$ for $108 \mathrm{ks}$.

に未再結晶組織とすることが多いので，冷延材にみるよ うな再結晶組織には問題が残る。

以上のことから7050合金をはじめとして Zr を含有す る合金では, $\mathrm{Al}_{3} \mathrm{Zr}$ 相の整合性が安定相の不均一析出に 大きな影響を及活すことがわかった。すなわち，安定相 $\eta$ は整合な $\mathrm{Al}_{3} \mathrm{Zr}$ 相へは不均一析出しないが，非整合な $\mathrm{Al}_{3} \mathrm{Zr}$ 相に不均一析出することが確かめられた。また過 時効処理（T73, T76）では結晶粒界上の析出相が粗大 化するためSCC 特性が向上するとされるが2)，この場 合粒内析出相も粗大化して強度低下をきたす。このとき Cr 系分散相は非整合であるため, 分散相上に安定相の 不均一析出を生じ強度はさらに低下する。これに対し $\mathrm{Zr}$ 系分散相は再結晶を生じない熱延材などでは整合性 を保つため, このような安定相の不均一析出を生じず, 過時効処理による強度低下の程度は小さい。したがって, Crに替わって Zr を添加した合金の方が焼入れ感受性に 優れるだけでなく，過時効処理後においても比較的高い 強度を保持でき，実用上有利であると判断される。

\section{4. 結言}

7075合金, 7050合金, および遷移元素 (Cr, Zr) に注 目して特別調製した7075類似合金について，いわゆる過 時効処理における安定相 $\eta$ の不均一析出挙動を調べた。 その結果， $\eta$ 相はいずれの合金でも結晶粒界（サブバウ ンダリーを含む）および第二相としての非整合な分散相 界面上へ優先的に析出することがわかった。しかし， $\mathrm{Zr}$ 系分散相は未再結晶組織の場合マトリックスと整合 であり, 安定相の析出サイトとはならない。そのため $\mathrm{Zr}$ 含有合金では過時効処理で強度低下が起きにくくな ることが示された。よって CrをZrに置き換えて整合 分散相を多く生じさせれば，過時効処理を行っても比較 的高い強度を保持できるといら実用上興味ある知見が得 られた。 


\section{参 考 文 献}

1) Recrystallization of Metallic Materials, (ed. by F. Haessner), Dr. Riederer-Verlag, (1978).

2) M. O. Speidel and M. V. Hyatt: Advances in Corrosion Science and Technology, vol. 2, Plenum Press, New York, (1972), 115.

3) M. O. Speidel: Met. Trans., 6A (1975), 631.

4) J. T. Staley: Aluminum, ASM, (1984), 185.

5）宮本学, 村上陽太郎：日本金属学会誌，37 (1973), 394.
6) P. N. Adler, R. Delasi and G. Geschwind: Metall. Trans., 3 (1972), 3191.

7）鈴木 寿, 菅野幹宏, 斉藤 洋, 系井一博 : 軽金 属, 33 (1983)， 29.

8）鈴木 寿, 菅野幹宏, 斉藤洋：軽金属，33 (1983), 399.

9) W. F. Smith and N. J. Grant: Met. Trans., 1 (1970), 1735.

10) K. Little, H. J. Axon and W. Hume-Rothery: J. Inst. Metals, 75 (1948), 39.

11) M. Kanno and B-L. Ou: Materials Trans. JIM, 32 (1991), 445. 